Magnussen, S. and A. D. YanchuK (1994): Time trends of predicted breeding values in selected crosses of coastal Douglas-fir in British Columbia: a methodological study. For Sci 40: 663-685.

MEYER, K. (2005): Random regression analyses using Bsplines to model growth of Australian Angus cattle. Genet Sel Evol 37: 473-500.

REHFELDT, G. E. (1995): Genetic variation, climate models and the ecological genetics of Larix occidentalis. For Ecol Manage 78: 21-37.

RUPPERT, D. (2002): Selecting the number of knots for penalized splines. Journal of Computational and Graphical Statistics 11: 735-757.

Ruppert, D., M. P. WAND and R. J. CARROLl (2003): Semiparametric Regression. Cambridge Univ Press, Cambridge, UK.

SAenz-Romero, C., E. V. Nordheim, R. P. Guries and P. M. CRUMP (2001): A case study of a provenance/progeny test using trend analysis with correlated errors and SAS PROC MIXED. Silvae Genet 50: 127-135.

Schabenberger, O. and C. A. Gotway (2005): Statistical Methods for Spatial Data Analysis. Boca Raton: Chapman \& Hall.

Silverman, B. (1986): Density Estimation for Statistics and Data Analysis. Chapman and Hall, London.

Smith, B. J. (2003): Bayesian Output Analysis Program (BOA) version 1.0 user's manual. http://www.publichealth.uiowa.edu/boa/Home.html. Cited 14 Aug 2008.
Spiegelhalter, D. J., N. G. Best, B. P. Carlin and A. Van DER LINDE (2002): Bayesian measures of model complexity and fit (with discussion). Journal of the Royal Statistical Society Series B 64: 583-639.

ST. Clair, J. B. (2006): Genetic variation in fall cold hardiness in coastal Douglas-fir in western Oregon and Washington. Can J Bot 84: 1110-1121.

Thomson, A. J. and Y. A. El-KassabY (1988): Trend surface analysis of provenance-progeny transfer data. Can J For Res 18: 515-520.

Verbyla, A. P., B. R. Cullis, M. G. Kenward and S. J. WELHAM (1999): The analysis of designed experiments and longitudinal data by using smoothing splines (with discussion). Applied Statistics 48: 69-311.

WAND, M. P. (2003): Smoothing and mixed models. Comput Stat 18: 223-249.

Woods, J. H., D. Kolotelo and A. D. YANChUK (1995): Early selection of coastal Douglas-fir in a farm-field environment. Silvae Genet 44: 178-186.

White, I. M. S., R. Thompson and S. Brotherstone (1999): Genetic and environmental smoothing of lactation curves with cubic splines. J Dairy Sci 82: 632-638.

YE, T. Z. and K. J. S. JAYAWICKRAMA (2008): Efficiency of using spatial analysis in firest-generation coastal Douglas-fir progeny tests in the US Pacific Northwest. Tree Genet Genomics 4: 677-692.

ZAS, R. (2006): Iterative kriging for removing spatial autocorrelation in analysis of forest genetic trials. Tree Genet Genomics 2: 177-185.

\title{
Clonal Variation in Lateral and Basal Rooting of Populus Irrigated with Landfill Leachate
}

\author{
By R. S. ZALESNY JR. ${ }^{*}$ and J. A. ZALESNY \\ U.S. Forest Service, Northern Research Station, Institute for Applied Ecosystem Studies, \\ 5985 Highway K, Rhinelander, WI 54501, U.S.A.
}

(Received 21 ${ }^{\text {th }}$ January 2010)

\begin{abstract}
Successful establishment and productivity of Populus depends upon adventitious rooting from: 1) lateral roots that develop from either preformed or induced primordia and 2) basal roots that differentiate from callus at the base of the cutting in response to wounding. Information is needed for phytotechnologies about the degree to which Populus adventitious rooting is controlled by effects of individual genotypes, waste waters used as alternative fertigation sources, and their interactions. Our objective was to irrigate twelve Populus clones with well water (control) or municipal solid waste landfill leachate and to test for differences between initiation of lateral versus basal roots, as well as root growth rate and distributional trends for both root types. We evalu-
\end{abstract}

\footnotetext{
*) Corresponding author (research plant geneticist):

Phone: +1 (715) 362-1132, Fax: +1 (715) 362-1166.

E-mail: rzalesny@fs.fed.us
}

ated number and length of lateral roots initiated from upper, middle, and lower thirds of the cutting, as well as basal callus roots. Overall, leachate irrigation affected lateral roots but not basal roots, and there was broad clonal variation between and within root types. On average, there were $129 \%$ more lateral than basal roots, which ranged from 3 to 27 (lateral) and 2 to 10 roots (basal). The percent advantage of number of roots from the middle portion of the cutting relative to other sections was $120 \%$ (upper), 193\% (lower), and 24\% (basal). Clones, treatments, and their interaction did not affect root growth rate, which ranged from $1.5 \pm 0.6$ to $3.4 \pm 0.3 \mathrm{~cm} \mathrm{~d}^{-1}$, with a mean of $2.3 \pm 0.2 \mathrm{~cm} \mathrm{~d}^{-1}$. These results contribute baseline information for clonal selection needed to establish Populus for phytotechnologies, energy, and fiber.

Key words: forest genetics, tree improvement, phytotechnologies, hybrid poplar, root types, Populus deltoides, P. trichocarpa, $P$. suaveolens subsp. maximowiczii, $P$. nigra. 


\section{Introduction}

Broad genetic variation among genotypes within the genus Populus has substantially contributed to its rich history of worldwide study and deployment (TAYLOR, 2002; RAJORA and ZsufFa, 1990; STOUT and SchreINER, 1933). Heterosis (i.e., hybrid vigor) of interspecific hybrids, along with traits such as disease/pest resistance and elevated rooting ability, has supported their use in a variety of applications (ZALESNY et al., 2009a; COYLE et al., 2008; HEILMAN et al., 1994). Fiber production is the traditional use of Populus in the North Central United States (ZALESNY et al., 2009b); however, the increasing need for alternative energy sources has supported testing and deployment of Populus species and hybrids for bioenergy, biofuels, and bioproducts (JOHNsON et al., 2007; SIMS et al., 2006). In addition, there is substantial interest in using Populus as an integral component of phytotechnologies such as phytoremediation and phytoextraction to gain environmental benefits

Table 1. - Composition (mean \pm standard error, $\mathrm{n}=2$ ) of municipal solid waste landfill leachate that was collected from the Oneida County Landfill in Rhinelander, Wisconsin, USA and used to irrigate twelve Populus clones.

Component

Concentration $\left(\mathrm{mg} \mathrm{L}^{-1}\right)$

\begin{tabular}{lr}
$\mathrm{pH}$ & $8.4 \pm 0.4$ \\
Electrical conductivity $(\mathrm{mS} \mathrm{cm}$ & -1 \\
Biological oxygen demand & $10.2 \pm 0$ \\
Chemical oxygen demand & $31 \pm 17$ \\
Nitrogen & $1050 \pm 50$ \\
Phosphorus & $745 \pm 15$ \\
Potassium & $2.1 \pm 0.1$ \\
Chloride & $450 \pm 30$ \\
\hline
\end{tabular}

throughout the region, North America, and globally (ZALESNY et al., 2008; BAÑUELOS et al., 1999).

Regardless of the end products or environmental services Populus trees provide, successful plantation development largely depends upon adventitious rooting, when trees are planted as dormant hardwood cuttings (ZALESNY and ZALESNY, 2009). Proper vegetation management and adequate fertilization and irrigation (fertigation) are equally important for the success of such short rotation woody crops (DESROCHERS et al., 2006; BuHLER et al., 1998; DiCKMANN et al., 1996). There is some information about the genetics of Populus adventitious rooting (ZALESNY et al., 2005; YING and BAGLEY, 1977; WILCOX and FARMER, 1968; 1967). Likewise, the effects of traditional fertigation sources on plantation development are well known (COYLE and COLEMAN, 2005; COLEMAN et al., 2004; BROWN and VAN DEN DRIESSCHE, 2002). However, there is limited knowledge in phytotechnology applications about the degree to which adventitious rooting is controlled by effects of individual genotypes, effects of waste waters used as alternative fertigation sources, and their interactions. It is necessary to acquire such information to advance opportunities for reusing and recycling waste waters while producing woody biomass for energy and fiber (ZALESNY et al., 2009a; 2007b; LICHT and IsEBRANDS, 2005).

We seek this combined knowledge to enhance our capability to select favorable genotypes exhibiting a combination of superior adventitious rooting and biomass accumulation when fertigated with contaminated waste waters. Our objective was to irrigate twelve Populus clones with well water (control) or municipal solid waste landfill leachate and to test for differences between initiation of lateral versus basal roots, as well as root growth rate and distributional trends for both root types. Our hypotheses were that clones would respond differently to water and leachate irrigation, and that clones would vary for all rooting traits. Overall, we assert this study helps researchers gain fundamental knowledge of the genetics and physiology of Populus adventitious rooting, while resource managers learn baseline information for clonal selection needed to establish Populus for phytotechnologies, energy, and fiber.

Table 2. - Genomic groups and clones of Populus irrigated with well water (control) and landfill leachate.

\begin{tabular}{|c|c|}
\hline Genomic group $^{\mathrm{a}}$ & Clone \\
\hline P. deltoides & 91.05 .02 \\
\hline$(P$. trichocarpa $\times P$. deltoides $) \times P$. deltoides & NC13460, NC13475, NC13680, NC14018 \\
\hline$P$. deltoides $\times P$. suaveolens & NC14104, NC14106, DM115 \\
\hline$P$. deltoides $\times P$. nigra & DN182, DN5 \\
\hline P. nigra $\times P$. suaveolens & NM2, NM6 \\
\hline
\end{tabular}

a Authorities for the species are: P. deltoides Bartr. ex Marsh; P. trichocarpa Torr. \& Gray; $P$. suaveolens Fischer subsp. maximowiczii A. Henry; P. nigra L. 


\section{Materials and Methods}

\section{Leachate description}

On 14 Jan. 2005, municipal solid waste leachate was collected from the Oneida County Landfill and transported $6 \mathrm{~km}$ to the Institute for Applied Ecosystem Studies (IAES) in Rhinelander, Wisconsin, USA $\left(45.6^{\circ} \mathrm{N}\right.$, $\left.89.4^{\circ} \mathrm{W}\right)$. The leachate was stored in air-tight, heavyduty plastic barrels at the IAES greenhouses. A sample of leachate was collected on 25 Jan. 2005 and 23 Feb. 2005 and tested for chemical composition using approved United States Environmental Protection Agency methods (Northern Lake Service, Inc., Crandon, Wisconsin, USA). Heavy metals, volatile organic compounds, and most inorganic elements were present in negligible quantities or not detectable and, therefore, not a concern for plant establishment. The concentration of chloride was of most concern given potential phytotoxic effects associated with salt stress. The concentration of chloride, as well as nitrogen, phosphorus, and potassi$\mathrm{um}$, is listed in Table 1, which also includes $\mathrm{pH}$, electrical conductivity, biological oxygen demand, and chemical oxygen demand. ZALESNY et al. (2007a) provided a detailed history of the changes in leachate composition since landfill closure in 2002.

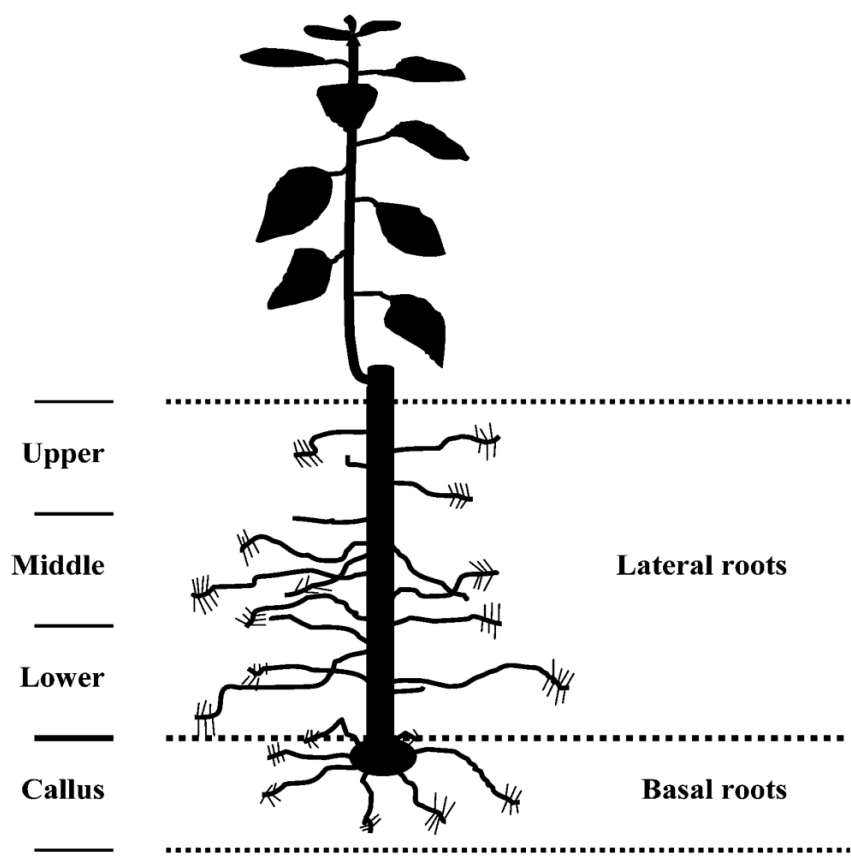

Figure 1. - Lateral and basal root types of Populus originating from upper, middle, and lower thirds of the hardwood cutting and callus, respectively.

Table 3. - Analysis of variance in an experiment testing adventitious rooting of twelve Populus clones irrigated with well water (control) or landfill leachate. Lateral roots developed along the upper, middle, and lower portions of hardwood cuttings, while basal roots developed from callus at the base of the cuttings. Probability values at $P<0.05$ are bolded.

\begin{tabular}{|c|c|c|c|c|}
\hline Source of variation & df & Mean square & $F$ variance ratio & $P$ value \\
\hline \multicolumn{5}{|c|}{ Number of lateral roots } \\
\hline Block & 5 & 40.59 & & \\
\hline Treatment & 1 & 697.84 & 3.23 & 0.1321 \\
\hline Block $\times$ Treatment & 5 & 215.82 & & \\
\hline Clone & 11 & 347.07 & 7.13 & $<0.0001$ \\
\hline Treatment $\times$ Clone & 11 & 94.81 & 1.95 & 0.0406 \\
\hline Pooled Error & 110 & 48.65 & & \\
\hline Total & 143 & & & \\
\hline \multicolumn{5}{|c|}{ Number of basal roots } \\
\hline Block & 5 & 96.02 & & \\
\hline Treatment & 1 & 7.56 & 0.32 & 0.5939 \\
\hline Block $\times$ Treatment & 5 & 23.35 & & \\
\hline Clone & 11 & 94.98 & 5.80 & $<0.0001$ \\
\hline Treatment $\times$ Clone & 11 & 9.58 & 0.59 & 0.8373 \\
\hline Pooled Error & 110 & 16.36 & & \\
\hline Total & 143 & & & \\
\hline
\end{tabular}




\section{Clone selection and cutting preparation}

Twelve Populus clones (Table 2) were selected from 25 original genotypes that were irrigated with leachate during Jan. 2005. Clonal selections were based on fifteen above- and below-ground traits following $14 \mathrm{~d}$ of growth: number of roots (four distinct traits), root dry mass (four distinct traits), root length, tree height, number of leaves, leaf area, leaf dry mass, stem dry mass, combined leaf and stem dry mass (ZALESNY et al., 2007a). The genomic groups consisted of the following parental species that are commonly used in breeding programs in the North Central United States: P. deltoides Bartr. ex Marsh (eastern cottonwood), P. trichocarpa Torr. \& Gray (western black poplar), P. suaveolens Fischer subsp. maximowiczii A. Henry (Japanese poplar), and P. nigra L. (European black poplar).
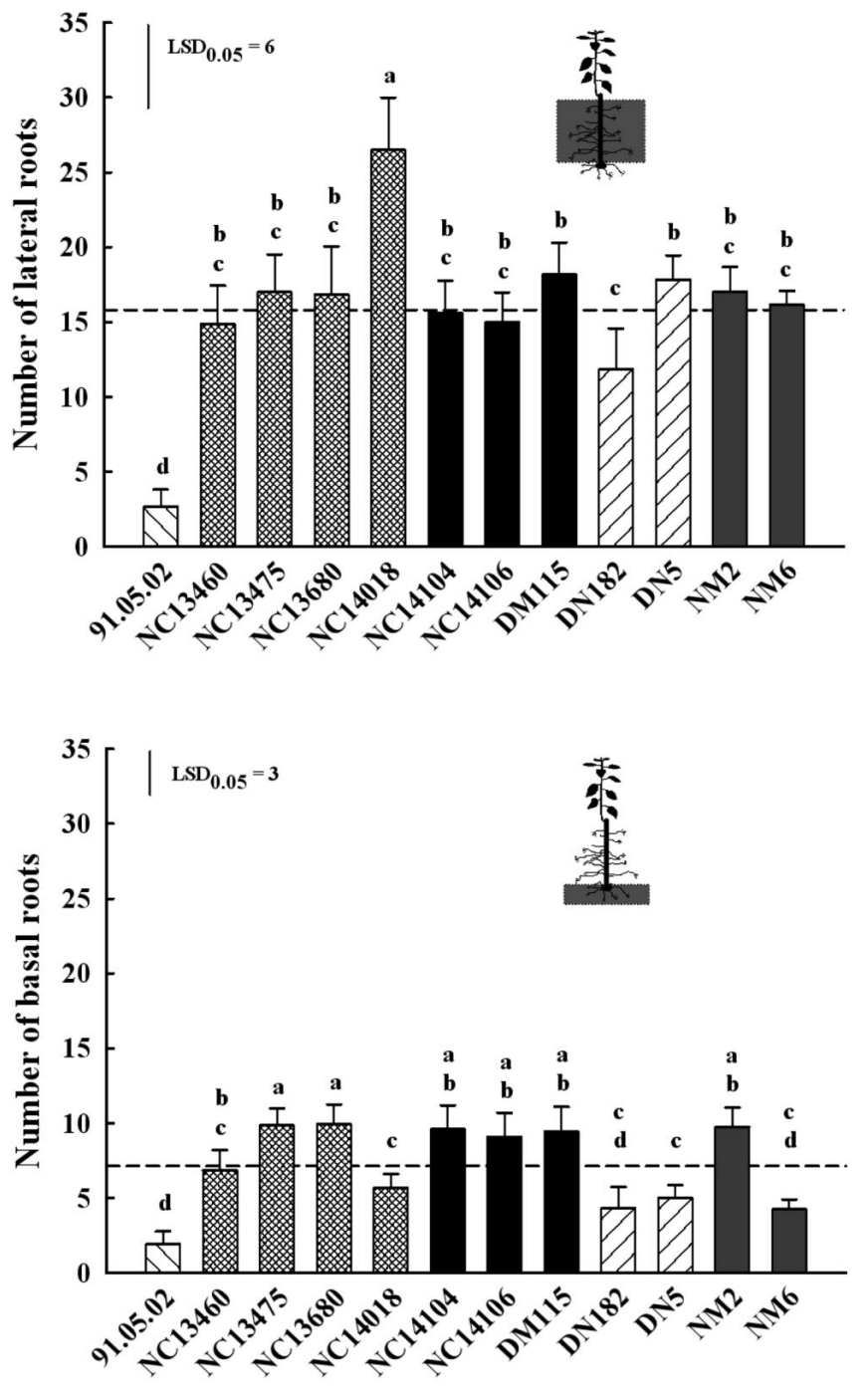

Clone

Figure 2. - Number of lateral (upper + middle + lower) and basal roots across irrigation treatments of 12 Populus clones irrigated with well water (control) or landfill leachate for $30 \mathrm{~d}$. Each bar represents the mean of 12 trees with one standard error, while the dashed bar represents the overall mean $(15.8 \pm 0.8$ lateral roots; $7.1 \pm 0.4$ basal roots $)$. Bars with the same letter were not different, according to Fisher's protected LSD at $P<0.05$.
Dormant, unrooted cuttings, 25.4-cm long, were processed from whips collected during Dec. 2005. The whips were grown for one growing season in stool beds established at Hugo Sauer Nursery in Rhinelander. During processing, cuts were made to position at least one primary bud not more than $2.54 \mathrm{~cm}$ from the top of each cutting. Cuttings were stored in polyethylene bags at $5{ }^{\circ} \mathrm{C}$, and then soaked in water to a height of $15 \mathrm{~cm}$ for $3 \mathrm{~d}$ before planting. The trees were grown from March through June 2005 in a greenhouse at the IAES with a 16 -h photoperiod and a daytime and nighttime temperature of $24^{\circ} \mathrm{C}$ and $20^{\circ} \mathrm{C}$, respectively.

\section{Experimental design}

Two separate studies testing 1) root initiation and 2) root growth rate were conducted and are described in detail below. For both studies, the trees were arranged in a split-plot design, with blocks (random), irrigation treatments (fixed whole plots), and clones (fixed sub plots). Treatments and clones were identical in both studies. Clones were arranged in randomized complete blocks to minimize effects of any potential environmental gradients in the greenhouse. Treatments and clones were considered as fixed in the analyses and, therefore, we evaluated means rather than variances. Block $\times$ clone effects were universally non-significant at $P>0.25$ and, therefore, pooled with the block $\times$ treatment $\times$ clone interaction terms to increase precision of F-tests (ZALESNY et al., 2005). The following linear additive model was used in the analyses:

$$
\mathrm{Y}_{\mathrm{ijk}}=\mu+\mathrm{B}_{\mathrm{i}}+\mathrm{T}_{\mathrm{j}}+\mathrm{BT}_{\mathrm{ij}}+\mathrm{C}_{\mathrm{k}}+\mathrm{TC}_{\mathrm{jk}}+\text { Pooled Error }
$$

where: $\mathrm{Y}_{\mathrm{ijk}}=$ response variable to be analyzed, $\mu=$ overall mean, $B_{i}=$ main effect of $i^{\text {th }}$ block, $T_{j}=$ main effect of $\mathrm{j}^{\text {th }}$ treatment, $\mathrm{BT}_{\mathrm{ij}}=$ effect of interaction between $\mathrm{i}^{\text {th }}$ block and $\mathrm{j}^{\text {th }}$ treatment, $\mathrm{C}_{\mathrm{k}}=$ main effect of $\mathrm{k}^{\text {th }}$ clone, $\mathrm{TC}_{\mathrm{jk}}=$ effect of interaction between $\mathrm{j}^{\text {th }}$ treatment and $\mathrm{k}^{\text {th }}$ clone, and pooled error = error term resulting from pooling of $\mathrm{BC}_{\mathrm{ik}}$ and $\mathrm{BTC}_{\mathrm{ijk}}$ terms, defined as: effect of interaction among $\mathrm{i}^{\text {th }}$ block and $\mathrm{k}^{\text {th }}$ clone, and effect of interaction among $\mathrm{i}^{\text {th }}$ block, $\mathrm{j}^{\text {th }}$ treatment, and $\mathrm{k}^{\text {th }}$ clone, respectively.

\section{Root initiation}

Tree establishment and irrigation regime

Six blocks, two irrigation treatments consisting of unfertilized well water (control) or landfill leachate, and 12 clones (144 experimental units) were tested. Trees were grown in specially-designed planters that allowed for evaluation of lateral roots developed from either preformed or induced primordia along the upper, middle, and lower third of the dormant hardwood cutting, as well as basal roots developed from callus at the base of the cutting in response to wounding (Fig. 1). ZALESNY et al. (2007a) described the planters in detail. The growing medium was sand to reduce experimental error associated with loss of roots during excavation and to supply an inert growing environment. The irrigation regime was $300-\mathrm{mL}$ water tree $\mathrm{e}^{-1} \mathrm{~d}^{-1}$ for a 10 - $\mathrm{d}$ establishment period, followed by irrigating with $300 \mathrm{~mL}$ tree $^{-1}$ of water or leachate on Mon., Wed., and Fri. for the remaining $20 \mathrm{~d}$ of the experiment. 
Table 4. - Analysis of variance in an experiment testing the number of adventitious roots of twelve Populus clones irrigated with well water (control) or landfill leachate. Root types were lateral roots developed along the upper, middle, and lower portions of hardwood cuttings, as well as basal roots developed from callus at the base of the cuttings. Probability values at $P<0.05$ are bolded.

\begin{tabular}{|c|c|c|c|c|}
\hline Source of variation & $\mathrm{d} \boldsymbol{c}^{\circ}$ & Mean square & $F$ variance ratio & $P$ value \\
\hline Block & 5 & 53.24 & & \\
\hline Treatment & 1 & 140.03 & 1.70 & 0.2487 \\
\hline Block $\times$ Treatment & 5 & 82.21 & & \\
\hline Clone & 11 & 149.45 & 6.61 & $<0.0001$ \\
\hline Block $\times$ Clone & 55 & 22.60 & & \\
\hline Treatment $\times$ Clone & 11 & 25.73 & 1.25 & 0.2791 \\
\hline Block $\times$ Treatment $\times$ Clone & 55 & 20.62 & & \\
\hline Root Type & 3 & 1027.13 & 37.92 & $<0.0001$ \\
\hline Block $\times$ Root Type & 15 & 27.08 & & \\
\hline Treatment $\times$ Root Type & 3 & 106.72 & 5.19 & 0.0117 \\
\hline Block $\times$ Treatment $\times$ Root Type & 15 & 20.55 & & \\
\hline Clone $\times$ Root Type & 33 & 41.27 & 3.62 & $<0.0001$ \\
\hline Block $\times$ Clone $\times$ Root Type & 165 & 11.41 & & \\
\hline Treatment $\times$ Clone $\times$ Root Type & 33 & 14.08 & 1.80 & 0.0088 \\
\hline Error & 165 & 7.82 & & \\
\hline Total & 575 & & & \\
\hline
\end{tabular}

Data collection and analysis

At 30 days after planting (DAP) the trees were harvested, washed, and dissected into root, stem, leaf, and cutting components. Callus formation was recorded. Twenty-six percent of the trees failed to initiate callus. Therefore, a Chi-square $\left(\chi^{2}\right)$ test from frequency counts was used to analyze differences for the presence of callus across treatments and clones (WIESE et al., 2006). However, these data must be interpreted with caution because most expected values in the $\chi^{2}$ table were estimated with a number of observations less than five. Furthermore, number of roots was recorded for each layer described above (i.e., upper, middle, lower, and callus). Number of upper, middle, and lower lateral roots was combined, and these data, along with number of basal roots, were subjected to analyses of variance (SAS INSTITUTE INC., 2004) according to the aforementioned split plot design with a random block effect and fixed main effects for irrigation treatment (whole plot) and clone (sub plot). Root type was added as a fixed sub sub plot factor to the model above (split split plot design) to test for differences in individual root types. Analyses of covariance were conducted to test for the effect of cutting dry mass on all traits because of a broad variation at $30 \mathrm{DAP}$ (1.08 to $7.51 \mathrm{~g}$ ). The effect of cutting dry mass was not significant for any rooting traits $(P>0.05)$. Interactions including the random block effect were universally significant at $P<0.25$ and, therefore, not pooled. Therefore, unadjusted means are reported for all variables. Fisher's protected least significant difference (LSD) was used to compare means from analyses of variance. Paired $t$-tests were used to compare the percent of root tissue allocated to root types between irrigation treatments for each clone. All means were considered different at probability values of $P<0.05$.

\section{Root growth rate}

Tree establishment and irrigation regime

Four blocks, two irrigation treatments (water or leachate), and 12 clones (96 experimental units) were tested. Trees were grown in specially-designed rhizotrons that supported two-dimensional, horizontal root growth measurements over time without disturbing aboveground tree growth. WIESE et al. (2005) and ZALESNY et al. (2007a) described the rhizotrons in detail. The growing medium was sand to support unambiguous identification of roots during digital root analysis and to supply an inert growing environment. The irrigation 

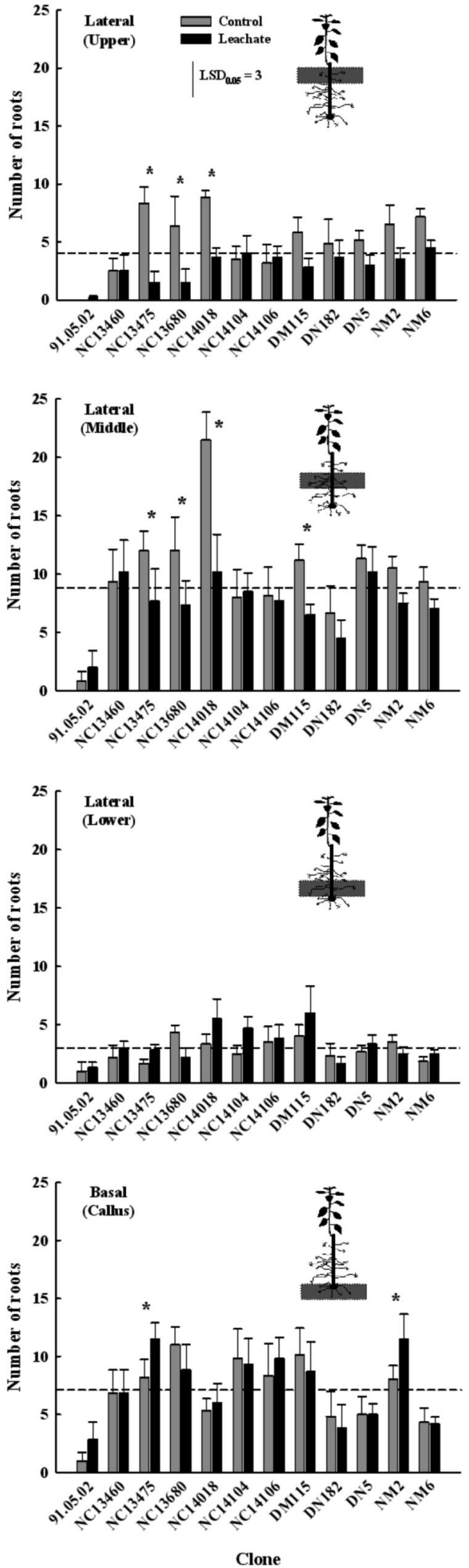

Figure 3. - Number of lateral and basal roots of 12 Populus clones irrigated with well water (control) or landfill leachate for $30 \mathrm{~d}$. Upper, middle, lower, and callus refers to the portion of the hardwood cutting from which roots originated. Each bar represents the mean of six trees with one standard error, while the dashed bars represent the overall mean for each root type. Treatments labeled with an asterisk within a clone were different, according to Fisher's protected LSD at $P<0.05$. regime was $30-\mathrm{mL}$ tree ${ }^{-1}$ of water or leachate on Mon., Wed., and Fri. for $45 \mathrm{~d}$. In addition, drip irrigation with water only was applied for 15-s intervals twice daily. The supplemental irrigation was applied to simulate natural rainfall and to meet the water demand of the trees.

\section{Data collection and analysis}

Digital photographs of the root systems were taken each Mon. and Thu. of the experimental period beginning 21 DAP, when roots were present on all clones. The photographs were subjected to digital analysis using WinRHIZO Tron software (Regent Instruments, Inc., Quebec, Canada) to determine total root length at 21, $24,28,31,35,38,42$, and 45 DAP. After $45 \mathrm{~d}$ the trees were harvested, washed, and dissected into roots, stems, leaves, and the cutting. Root length data were converted to root growth rate by calculating the difference between length at consecutive dates and dividing by the number of days between measurements [e.g., root growth

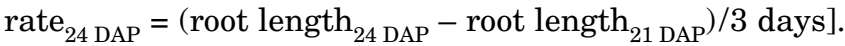
Root growth rate data were subjected to repeated measures analyses of variance (SAS INSTITUTE INC., 2004) according to a split plot, repeated measures design with a random block effect and fixed main effects for irrigation treatment (whole plot) and clone (sub plot). The repeated measure was time (i.e., DAP). Given correlated errors associated with DAP, the results from multivariate analyses of variance (MANOVA) were interpreted to provide correct $\mathrm{F}$-variance ratios and to reduce the probability of incorrectly claiming significant differences when, in fact, there were none (i.e., Type I Errors). Analyses of covariance were conducted to test for the effect of cutting dry mass on all traits because of a broad variation at $45 \mathrm{DAP}$ (1.41 to $9.04 \mathrm{~g}$ ). The effect of cutting dry mass was not significant $(P>0.05)$. Therefore, unadjusted means are reported for all variables. Means were compared as with root initiation data.

\section{Results}

\section{Lateral and basal root initiation}

Irrigation treatments did not affect number of lateral roots $(P=0.1321)$, but the clone main effect $(P<0.0001)$ and treatment $\times$ clone interaction $(P=0.0406)$ were significant (Table 3). This interaction is described in greater detail below. Overall, the number of lateral roots among clones ranged from $3 \pm 1$ roots (91.05.02) to $27 \pm 3$ roots (NC14018), with a mean of $16 \pm 1$ roots (Fig. 2 ). With the exception of clone 91.05 .02 (P. deltoides parentage), genomic groups exhibited similar numbers of lateral roots. Clones within genomic groups also initiated comparable numbers, with two exceptions. Clone NC14018 had 1.6 to 1.8 times more roots than the other clones of $(P$. trichocarpa $\times P$. deltoides $) \times P$. deltoides parentage, and clone DN5 had 1.5 times more roots than DN182 within the $P$. deltoides $\times P$. nigra genomic group.

The main effect of treatment was not significant for the presence of callus $(P=0.1304)$, while clones differed $(P=0.0006)$. However, the treatment $\times$ clone interaction controlled the presence of callus $(P=0.0074)$ (Table 3$)$. Overall, callus developed on $79 \%$ (water treatment) and 


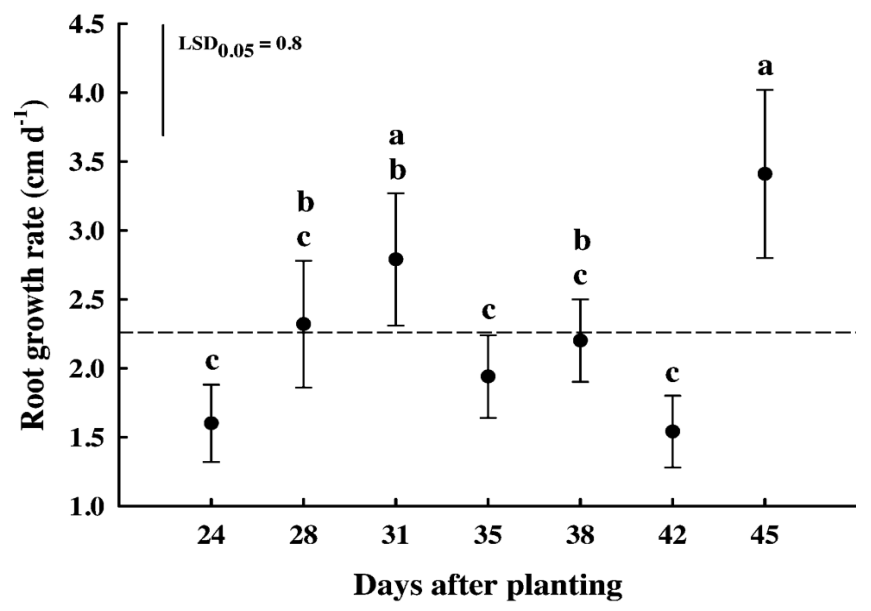

Figure 4. - Root growth rate versus days after planting across 12 Populus clones irrigated with well water (control) or landfill leachate for $45 \mathrm{~d}$. Each point represents the mean of 96 trees with one standard error, while the dashed bar represents the overall mean $\left(2.3 \pm 0.4 \mathrm{~cm} \mathrm{~d}^{-1}\right)$. Points with the same letter were not different, according to Fisher's protected LSD at $P<0.05$.

$68 \%$ (leachate treatment) of the trees, with a mean of $74 \%$. The frequency of trees developing or failing to develop callus was stable ( \pm two trees) across treatments for all genotypes except clone NC14018, whereby five of six trees developed callus when irrigated with water but only two of six trees developed callus for the leachate treatment. In contrast, trees of clone NC13680 exhibited less callus development than the other genotypes, with four of six (water) and five of six (leachate) trees failing to develop callus. Nevertheless, irrigation treatments $(P=0.5939)$ and their interaction with clones $(P=0.8373)$ did not affect number of basal roots, but the clone main effect $(P<0.0001)$ was significant (Table 3). Overall, the number of basal roots among clones ranged from $2 \pm 1$ roots $(91.05 .02)$ to $10 \pm 1$ roots (NC13680), with a mean of $7 \pm 0$ roots that was $44 \%$ of the number of lateral roots (Fig. 2). There was broad variation among genomic groups and clones for number of basal roots. In general, clones with P. deltoides $\times$ $P$. suaveolens parentage exhibited the greatest number of basal roots, which was similar to two (P. trichocarpa $\times$ $P$. deltoides $) \times P$. deltoides clones and one P. nigra $\times$ $P$. suaveolens clone. Specifically, clones NC13475 and NC13680 had 1.6 times greater number of basal roots than NC13460 and NC14018 in their genomic group, while clone NM2 had 2.3 times more roots than NM6.

There were differences among clones $(P<0.0001)$ and root types $(P<0.0001)$ for number of roots, as well as the interaction of root type with irrigation treatment $(P=0.0117)$ and clone $(P<0.0001)$. However, the threeway interaction among treatment, clone, and root type $(P=0.0088)$ governed the number of roots, which corroborated the significant treatment $\times$ clone interaction for number of lateral roots (Table 4). Overall, the number of roots initiated from the middle third of the cutting was greater by $120 \%$ of the upper, $193 \%$ of the lower, and $24 \%$ of the basal root sections (Fig. 3). There was broad variation among genomic groups and clones within all

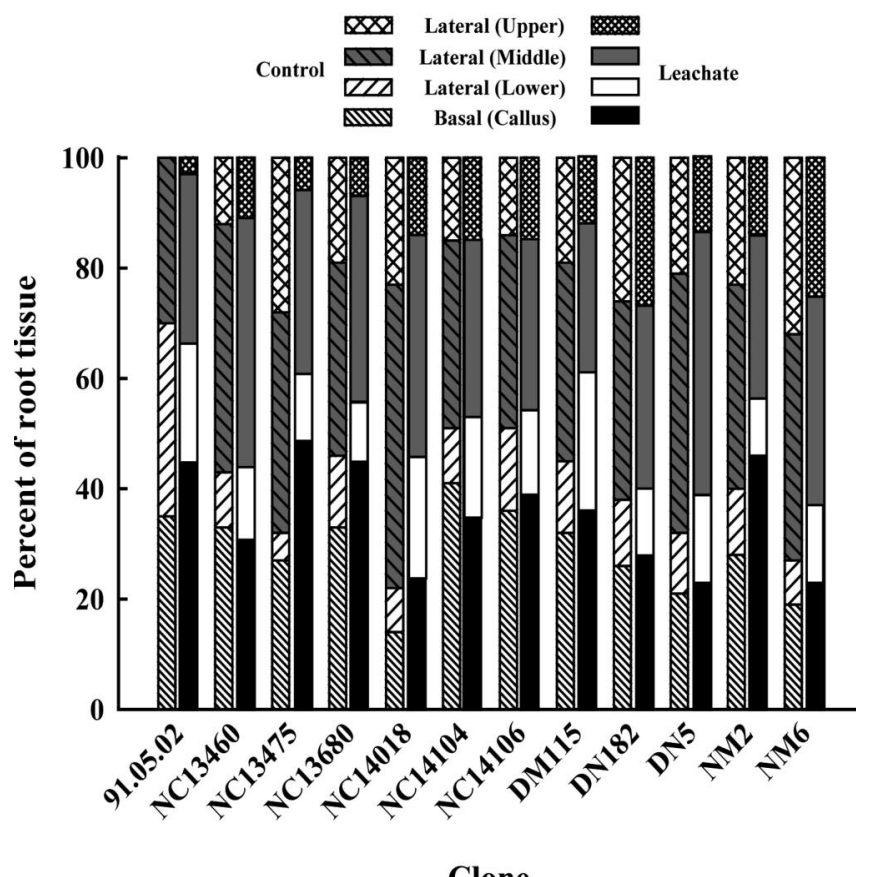

\section{Clone}

Figure 5. - Percent of root tissue, based on number of roots, allocated to lateral and basal roots of 12 Populus clones irrigated with well water (control) or landfill leachate for $30 \mathrm{~d}$. Upper, middle, lower, and callus refers to the portion of the hardwood cutting from which roots originated. Each bar represents the mean of six trees.

four root types, with a general trend of genotypes belonging to $(P$. trichocarpa $\times P$. deltoides $) \times P$. deltoides and $P$. deltoides $\times P$. suaveolens parentage having the greatest number of roots. Trees irrigated with water exhibited more upper lateral roots than those with leachate for clones NC13475 (453\% more roots), NC13680 (320\%), and NC14018 (138\%). Water-irrigated trees also had greater numbers of middle lateral roots for NC13475 (56\%), NC13680 (64\%), NC14018 (111\%), and DM115 (72\%). In contrast, number of basal roots was greater following leachate irrigation for NC13475 $(40 \%)$ and NM2 (44\%).

\section{Root growth rate}

Clones, treatments, and their interaction did not affect root growth rate from 24 to 45 days after planting (DAP) $(P>0.05)$. However, root growth rate changed over time $\left(P_{\text {MANOVA }}<0.0001\right)$, increasing by $75 \%$ from 24 to 31 DAP, followed by a decrease of $46 \%$ until 42 DAP, and a second significant increase of $127 \%$ at 45 DAP (Fig. 4). Overall, roots grew $1.5 \pm 0.6$ to $3.4 \pm 0.3 \mathrm{~cm} \mathrm{~d}^{-1}$, with a mean of $2.3 \pm 0.2 \mathrm{~cm} \mathrm{~d}^{-1}$.

\section{Distributional trends across root types}

The irrigation treatment $\times$ clone interaction affected distributional trends in the percent of root tissue allocated to lateral and basal root types, based on number of roots. Across treatments, approximately two-thirds of the roots were lateral and one-third developed from callus (Fig. 5). However, trees irrigated with water exhibited $5 \%$ more upper lateral roots than those of the leachate treatment $(P=0.0169)$, which was similar to 
A

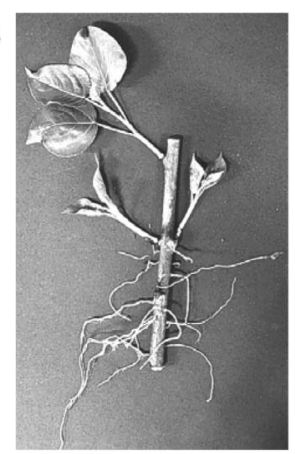

B

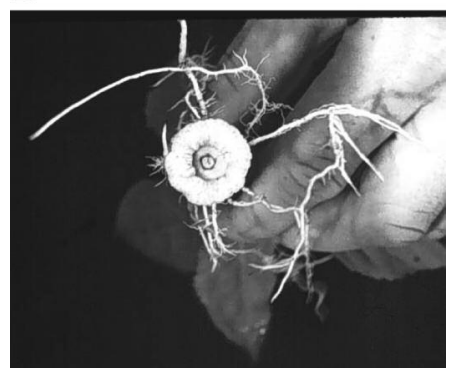

Figure 6. - Adventitious roots of Populus: lateral roots along length of cutting (A) and basal roots from callus at the base of the cutting $(\mathrm{B})$.

$4 \%$ more middle lateral roots with water than leachate irrigation $(P=0.0181)$. The percent of lower lateral root tissue did not differ between treatments $(P=0.1803)$, but there was $6 \%$ more basal roots from leachate-irrigated trees compared with water-irrigated trees $(P=0.0168)$. Overall, the percent of root tissue allocated across root types was highly variable among genomic groups and clones. For example, the distributional trend of root types was nearly identical between treatments for clones of the $P$. deltoides $\times P$. suaveolens and $P$. deltoides $\times P$. nigra genomic groups, while that for (P. trichocarpa $\times P$. deltoides $) \times P$. deltoides clones was very different (Fig. 5).

\section{Discussion}

Leachate irrigation had a greater relative effect on the initiation of lateral versus basal adventitious roots. Nevertheless, the high-salinity leachate used as an alternative fertigation source did not significantly reduce initiation, growth rate, or distributional trends of either root type. This is important given that Populus genotypes have exhibited salt sensitivities with electrical conductivity ranging from 1 to $5 \mathrm{mS} \mathrm{cm}{ }^{-1}$ (NEUMAN et al., 1996), which is less than half of that used in the current study $\left(10.2 \mathrm{mS} \mathrm{cm}{ }^{-1}\right)$. Overall, the lack of detrimental physiological responses associated with salt stress during root initiation was promising for early survival. In addition, genotype-specific responses to the leachate and water irrigation treatments were important from a tree genetics and breeding perspective. For example, clones belonging to the $(P$. trichocarpa $\times P$. deltoides $) \times P$. deltoides genomic group exhibited greater numbers of upper and middle lateral roots when irrigated with water, while differences in the number of lower lateral roots were negligible across genotypes; clone NC13475 produced significantly more basal roots with leachate irrigation versus water. In contrast, the effect of irrigation treatments on adventitious rooting of clones with $P$. deltoides $\times P$. nigra parentage was the same, regardless of root type. Selection both among and within genomic groups is necessary to ensure root initiation during establishment and to maintain adequate diversity as the trees develop.

Although there were nearly twice as many lateral roots as basal roots across treatments and clones, leachate irrigation equally affected both root types (Fig. 2). ZALESNY et al. (2009a; 2007b) reported similar results for dry mass of lateral and basal roots when field-testing eight of the twelve current clones during two years of establishment at the Oneida County Landfill in northern Wisconsin. Only clone NC14018 of (P. trichocarpa $\times$ $P$. deltoides $) \times P$. deltoides parentage had greater lateral root dry mass with water versus leachate, while all other irrigation treatment comparisons for individual root types were non-significant (ZALESNY et al., 2007b). Moreover, to increase our fundamental knowledge of Populus adventitious rooting, we classified lateral and basal roots based on their differing sites of initiation and development from the dormant hardwood cuttings (ZALESNY et al., 2009a) (Fig. 6). Although the objectives of the study did not support direct anatomical testing, we assumed given the short duration of the study that lateral roots developed from latent, preformed primordia laid down during the previous growing season (FARMER et al., 1989; SмITH and WAREING, 1974) rather than induced roots initiated as a response to current external stimuli (HAISSIG, 1974). All basal roots differentiated from parenchymous masses (i.e., callus) at the base of the cuttings in response to wounding imposed by processing parent shoots into the propagules (HAISSIG, 1974). The differences in lateral and basal root numbers may be explained by increased areas of meristematic activity and associated primordia along the length of the parent shoot relative to the more restricted region of callus development at the base of the cuttings (FARMER et al., 1989; SMITH and WAREING, 1974).

In general, we expected increased carbohydrate content to allow the cuttings of favorable genotypes (i.e., basal rooting of clones NC13475 and NM2; Fig. 3) to be more tolerant of environmental stresses such as that imposed by the high-salinity leachate irrigation. Accumulation and partitioning of carbohydrates within cuttings has been shown to affect adventitious rooting of Populus (Tschaplinski and Blake, 1989; OKORO and GRACE, 1976), with larger cuttings exhibiting greater carbohydrate content (FEGE and BROWN, 1984). NGUYEN et al. (1990) reported increased survival and root system production associated with greater levels of carbohydrates of clones DN34 (P. deltoides $\times$ P. nigra) and Tristis \#1 (P. tristis Fisch. $\times$ P. balsamifera L.) grown at the Michigan State University Tree Research Center $\left(42.4^{\circ} \mathrm{N}, 84.3^{\circ} \mathrm{W}\right)$ for one growing season. Likewise, the greatest levels of total carbohydrate content of clone 178 ( $P$. deltoides $\times P$. nigra $)$ were in basal sections of cut- 
tings directly before root initiation (OKORO and GRACE, 1976). In this study the relationship between cutting size and root initiation/growth was inconclusive in saline environments imposed by leachate irrigation. However, these relationships warrant further study.

Variability in initiation, growth rate, and distributional trends of adventitious roots was due to the effects of interactions among specific clones and irrigation treatments. Adventitious rooting of Populus is under strong genetic control (YING and BAGLEY, 1977; WILCOX and FARMER, 1968; 1967). However, substantial variability in rooting responses among genotypes has been the result of other factors such as: propagation conditions (Desrochers and Thomas, 2003; Hansen and Tolsted, 1981), positional effects and environmental preconditioning of the parent shoots (i.e., C-effects) (FARMER et al., 1989 ; 1988; 1986), and genotype $\times$ environment interactions (ZALESNY et al., 2005; RIEMENSCHNEIDER and BAUER, 1997). As with the clones of the current study, the uncertainty of predicting adventitious rooting of specific Populus genotypes is heightened during phytotechnology applications given heterogeneous growing conditions associated with varying contaminant levels (ZALESNY et al., 2009a; 2008). Although leachate irrigation affected individual root types similarly, there was broad variation among and within genomic groups for overall root initiation. ZALESNY et al. (2007b) reported comparable genotypic variability for eight of the twelve clones tested in the current study. An P. deltoides $\times$ P. suaveolens subsp. maximowiczii $\mathrm{F}_{1}$ hybrid (clone NC14104) was identified that exhibited greater total root dry mass when irrigated with leachate versus water, compared with two clones that rooted better with water and five clones that had similar root dry mass regardless of irrigation treatment (ZALESNY et al., 2007b). Such genotype $\times$ environment interactions have supported the need for selection of generalist genotypes that perform well across a broad range of unpredictable conditions or specialist genotypes that are well-adapted for specific conditions (ZALESNY et al., 2008).

The biological and economic importance of adventitious rooting is reflected in its incorporation as a key trait in Populus breeding programs (RIEMENSCHNEIDER and BAUER, 1997). Equally important is the incorporation of adventitious rooting as a primary criterion when selecting favorable Populus genotypes for environmental benefits (ZALESNY and ZALESNY, 2009). Successful rooting decreases establishment/vegetation management costs and increases operational flexibility of planting schedules in the short-term. Rooting also enhances environmental sustainability through contaminant interception and hydraulic control in the long-term. Our results corroborated those of many Populus rooting studies in that root initiation and growth depended on how the genotypes responded to an environmental stimulus, in this case the landfill leachate versus water. The results of the current study contribute fundamental knowledge of the genetics and physiology of Populus adventitious rooting that is important for advancing the use of these short rotation woody crops for environmental benefits, energy, and fiber. For example, the increasing need for using Populus in phytotechnologies requires matching adventitious rooting, specific contaminant chemistry, and favorable genotypes to increase the potential success of plantation establishment and subsequent environmental services. More specifically, our baseline information fills knowledge gaps for using adventitious rooting as a selection criterion in Populus breeding, especially with respect to using Populus in phytotechnologies such as phytoremediation and phytoextraction.

\section{Acknowledgements}

We thank Dr. NEIL NELSON for support during all stages of this project, as well as Mr. ADAM WIESE for technical assistance. We are grateful to the following people for review of earlier versions of the manuscript: Edmund Bauer, David Coyle, William Headlee, Neil NELSON, and TOM SCHMIDT.

\section{References}

Bañuelos, G. S., M. C. Shannon, H. Ajwa, J. H. Draper, J. JoRDAHL and L. LICHT (1999): Phytoextraction and accumulation of boron and selenium by poplar (Populus) hybrid clones. Int. J. Phytoremed. 1: 81-96.

BROwN, K. R. and R. VAN DEN DRIESSCHE (2002): Growth and nutrition of hybrid poplars over 3 years after fertilization at planting. Can. J. For. Res. 32: 226-232.

Buhler, D. D., D. A. Netzer, D. E. Riemenschneider and R. G. HARTZLER (1998): Weed management in short rotation poplar and herbaceous perennial crops grown for biofuel production. Biomass Bioenergy 14: 385-394.

Coleman, M. D., A. L. Friend and C. C. Kern (2004): Carbon allocation and nitrogen acquisition in a developing Populus deltoides plantation. Tree Physiol. 24: 1347-1357.

Coyle, D. R. and M. D. Coleman (2005): Forest production responses to irrigation and fertilization are not explained by shifts in allocation. For. Ecol. Manage. 208: $137-152$.

Coyle, D. R., E. R. Hart, J. D. McMillin, L. C. Rule and R. B. HALL (2008): Effects of early repeated cottonwood leaf beetle defoliation on Populus growth and economic potential over a full harvest rotation. For. Ecol. Manage. 260: 3365-3373.

DesRochers, A. and B. R. Thomas (2003): A comparison of pre-planting treatments on hardwood cuttings of four hybrid poplar clones. New For. 26: 17-32.

DesRochers, A., R. van DEN DRIEssche and B. R. Thomas (2006): NPK fertilization at planting of three hybrid poplar clones in the boreal region of Alberta. For. Ecol. Manage. 232: 216-225.

Dickmann, D. I., P. V. NGuyen and K. S. Pregitzer (1996): Effects of irrigation and coppicing on above-ground growth, physiology, and fine-root dynamics of two fieldgrown hybrid poplar clones. For. Ecol. Manage. 80: $163-174$.

Farmer, R. E., JR., M. Freitag and K. Garlick (1989): Genetic variance and "C" effects in balsam poplar rooting. Silvae Genet. 38: 62-65.

FARMER, R. E., JR., K. GARLICK and S. R. WATSON (1988): Heritability and C effects in a 3-year-old balsam poplar clonal test. Can. J. For. Res. 18: 1059-1062.

FARMeR, R. E., JR., R. W. REINholt and F. SchnekenBERGER (1986): Environmental preconditioning and variance in early growth of balsam poplar. Silvae Genet. 35: $129-131$. 
FEGE, A. S. and G. N. Brown (1984): Carbohydrate distribution in dormant Populus shoots and hardwood cuttings. For. Sci. 30: 999-1010.

HAISsig, B. E. (1974): Origins of adventitious roots. New Zealand J. For. Sci. 4: 299-310.

HANsen, E. A. and D. N. Tolsted (1981): Effect of cutting diameter and stem or branch position on establishment of a difficult-to-root clone of a Populus alba hybrid. Can. J. For. Res. 11: 723-727.

Heilman, P. E., G. Ekuan and D. B. Fogle (1994): Aboveand below-ground biomass and fine roots of 4-year-old hybrids of Populus trichocarpa $\times$ Populus deltoides and parental species in short-rotation culture. Can. J. For. Res. 24: 1186-1192.

Johnson, J. M-F., M. D. Coleman, R. Gesch, A. Jaradat, R. Mitchell, D. Reicosky and W. W. Wilhelm (2007): Biomass-bioenergy crops in the United States: a changing paradigm. Amer. J. Plant Sci. Biotechnol. 1: 1-28.

LichT, L. A. and J. G. IsEBRANDS (2005): Linking phytoremediated pollutant removal to biomass economic opportunities. Biomass Bioenergy 28: 203-218.

Neuman, D. S., M. Wagner, J. H. BraAtne and J. Howe (1996): Stress physiology - abiotic, pp. 423-458. Biology of Populus and Its Implications for Management and Conservation. Part II, Chapter 17. NRC Research Press, National Research Council of Canada, Ottawa, ON K1A 0R6, Canada.

Nguyen, P. V., D. I. Dickmann, K. S. Pregitzer and R. HENDRICK (1990): Late-season changes in allocation of starch and sugar to shoots, coarse roots, and fine roots in two hybrid poplar clones. Tree Physiol. 7: 95-105.

OKoro, O. O. and J. Grace (1976): The physiology of rooting Populus cuttings. I. Carbohydrate and photosynthesis. Physiol. Plant. 36: 133-138.

RAJORA, O. M. and L. ZsuFfa (1990): Allozyme divergence and evolutionary relationships among Populus deltoides, P. nigra, and $P$. maximowiczii. Genome 33: 44-49.

Riemenschneider, D. E. and E. O. BAuer (1997): Quantitative genetic analysis of adventitious root forming ability in Populus trichocarpa (TORR ET. GRAY), pp. 193-201. In: A. Altman and Y. WAisel (eds). Biology of Root Formation and Development. Plenum Press, New York.

SAS InstituTe, Inc. (2004): SAS/STAT ${ }^{\circledR} 9.1$ User's Guide. Cary, NC.

Sims, R. E. H., A. Hastings, B. Schlamadinger, G. TayloR and P. SMith (2006): Energy crops: current status and future prospects. Global Change Biol. 12: 2054-2076.

SMITH, N. G. and P. F. WAREING (1974): The distribution of latent root primordia in stems of Populus $\times$ robusta, and factors affecting the emergence of preformed roots from cuttings. Forestry 45: 197-209.

Stout, A. B. and E. J. Schreiner (1933): Results of a project in hybridizing poplars. J. Hered. 24: 216-229.
TAYLOR, G. (2002): Populus: Arabidopsis for forestry. Do we need a model tree? Annal. Bot. 90: 681-689.

Tschaplinski, T. J. and T. J. Blake (1989): Correlation between early root production, carbohydrate metabolism, and subsequent biomass production in hybrid poplar. Can. J. Bot. 67: 2168-2174.

Wiese, A. H., J. A. Zalesny, D. M. Donner and R. S. ZALESNY, JR. (2006): Bud removal affects shoot, root, and callus development of hardwood Populus cuttings. Silvae Genet. 55: 141-148.

Wiese, A. H., D. E. Riemenschneider and R. S. ZAlesny, JR. (2005): An inexpensive rhizotron design for twodimensional, horizontal root growth measurements. Tree Plant. Not. 51: 40-46.

Wilcox, J. R. and R. E. FARMER, JR. (1968): Heritability and $\mathrm{C}$ effects in early root growth of eastern cottonwood cuttings. Heredity 23: 239-245.

WILCOX, J. R. and R. E. FARMER, JR. (1967): Variation and inheritance of juvenile characters of eastern cottonwood. Silvae Genet. 16: 162-165.

YING, C. C. and W. T. BAGLEY (1977): Variation in rooting capability of Populus deltoides. Silvae Genet. 26: 204-207.

Zalesny, J. A., R. S. Zalesny, JR., D. R. Coyle, R. B. HALL, and E. O. BAUER (2009a): Clonal variation in morphology of Populus root systems following irrigation with landfill leachate or water during two years of establishment. BioEnergy Res. 2: 134-143.

Zalesny, J. A., R. S. ZAlesny, JR., A. H. Wiese, B. SeXton and R. B. HALL (2008): Sodium and chloride accumulation in leaf, woody, and root tissue of Populus after irrigation with landfill leachate. Environ. Poll. 155: 72-80.

Zalesny, J. A., R. S. Zalesny, JR., A. H. Wiese and R. B. HALL (2007a): Choosing tree genotypes for phytoremediation of landfill leachate using phyto-recurrent selection. Intl. J. Phytoremed. 9: 513-530.

Zalesny, J. A., R. S. Zalesny, JR., D. R. Coyle and R. B. HALL (2007b): Growth and biomass of Populus irrigated with landfill leachate. For. Ecol. Manage. 248: 143-152.

ZALESNY, R. S., JR. and J. A. ZALESNY (2009): Selecting Populus with different adventitious root types for environmental benefits, fiber, and energy. Ch. 18. In: K. Niemi and C. ScAGEL (eds). Adventitious Root Formation of Forest Trees and Horticultural Plants - From Genes to Applications. Chapter 18. Research Signpost. pp. 359-384.

Zalesny, R. S., JR., R. B. Hall, J. A. Zalesny, B. G. McMahon, W. E. Berguson, and G. R. Stanosz (2009b): Biomass and genotype $\times$ environment interactions of Populus energy crops in the Midwestern United States. BioEnergy Res. 2: 106-122.

ZAlesny, R. S., JR., D. E. Riemenschneider and R. B. HALL (2005): Early rooting of dormant hardwood cuttings of Populus: analysis of quantitative genetics and genotype $\times$ environment interactions. Can. J. For. Res. 35: $918-929$.

Herausgeber: Johann Heinrich von Thünen-Institut. Bundesforschungsinstitut für Ländliche Räume, Wald und Fischerei. Schriftleitung: Institut für Forstgenetik, Sieker Landstraße 2, D-22927 Großhansdorf

Verlag: J. D. Sauerländer's Verlag, Finkenhofstraße 21, D-60322 Frankfurt a. M. Anzeigenverwaltung: J. D. Sauerländer's Verlag, Frankfurt am Main.

Gesamtherstellung: PPPP Norbert Wege e.K., Gladenbach — Printed in Germany. 